\title{
The Effects of Sulglycotide on the Adhesion and the Inflammation of Helicobacter Pylori
}

\author{
Ji Yeong Yang ${ }^{1, \dagger}$, Pumsoo Kim ${ }^{2, \dagger}$, Seok-Hoo Jeong ${ }^{2, * \mathbb{D}}$, Seong Woong Lee ${ }^{3}$, Yu Sik Myung ${ }^{2}$, \\ Myong Ki Baeg ${ }^{2}$ and Jong-Bae Kim ${ }^{1, *(D)}$ \\ 1 Department of Biomedical Laboratory Science, College of Health Sciences, Yonsei University, Wonju 26493, \\ Korea; clever1088@nate.com \\ 2 Division of Gastroenterology, Department of Internal Medicine, Catholic Kwandong University \\ International St. Mary's Hospital, Incheon 22711, Korea; pskimgi@naver.com (P.K.); \\ dittomyung@gmail.com (Y.S.M.); baegmk@gmail.com (M.K.B.) \\ 3 Samil Pharmaceutical Co. Ltd., Seoul 06666, Korea; citos@samil-pharm.com \\ * Correspondence: ssukoo@naver.com (S.-H.J.); kimjb70@yonsei.ac.kr (J.-B.K.); Tel.: +82-32-290-3302 (J.-B.K.) \\ + Ji Yeong Yang and Pumsoo Kim contributed equally to this work.
}

Received: 6 April 2020; Accepted: 23 April 2020; Published: 23 April 2020

\begin{abstract}
Helicobacter pylori (H. pylori) is a primary etiologic factor in gastric diseases. Sulglycotide is a glycopeptide derived from pig duodenal mucin. Esterification of its carbohydrate chains with sulfate groups creates a potent gastroprotective agent used to treat various gastric diseases. We investigated the inhibitory effects of sulglycotide on adhesion and inflammation after $H$. pylori infection in human gastric adenocarcinoma cells (AGS cells). H. pylori reference strain 60190 (ATCC 49503) was cultured on Brucella agar supplemented with $10 \%$ bovine serum. Sulgylcotide-mediated growth inhibition of $H$. pylori was evaluated using the broth dilution method. Inhibition of $H$. pylori adhesion to AGS cells by sulglycotide was assessed using a urease assay. Effects of sulglycotide on the translocation of virulence factors was measured using western blot to detect cytotoxin-associated protein A (CagA) and vacuolating cytotoxin A (VacA) proteins. Inhibition of IL-8 secretion was measured using enzyme-linked immunosorbent assay (ELISA) to determine the effects of sulglycotide on inflammation. Sulglycotide did not inhibit the growth of H. pylori, however, after six and 12 hours of infection on AGS cells, H. pylori adhesion was significantly inhibited by approximately $60 \%$ by various concentrations of sulglycotide. Sulglycotide decreased $H$. pylori virulence factor (CagA and VacA) translocation to AGS cells and inhibited IL-8 secretion. Sulglycotide inhibited H. pylori adhesion and inflammation after infection of AGS cells in vitro. These results support the use of sulglycotide to treat $H$. pylori infections.
\end{abstract}

Keywords: adhesion; helicobacter pylori; inflammation; sulglycotide

\section{Introduction}

Helicobacter pylori (H. pylori) is a helical Gram-negative bacterium that penetrates gastric mucosa and colonizes the stomach [1]. H. pylori infection is associated with numerous gastric diseases [2,3], initiates acute inflammatory reactions and progresses chronic inflammatory reactions, atrophic gastric mucosal changes, intestinal metaplasia, dysplasia, and finally carcinogenesis, which is known as the inflammation-carcinoma chain [4]. Therefore, H. pylori is classified as a type I carcinogen [1]. H. pylori infection might persist for many years without inducing gastrointestinal symptoms, even though $1 \%$ to $3 \%$ of infected human hosts develop gastric cancer $[5,6]$. The prevalence of $H$. pylori infection exceeds half of the world's population. In South Korea, the prevalence is 50\% to $80 \%$ in $40-50$-year-olds with approximately 12 49\% of 16-19-year-olds infected [7], as such, gastric diseases including gastric cancer is likely to be high in South Korea. 
The H. pylori lipopolysaccharide has a particularly significant role in virulence [8,9]; it stimulates the upregulation of pro-inflammatory cytokines, excessive generation of nitric oxide, and regression of regulatory cytokines $[8,10]$. In previous studies, two $H$. pylori-associated virulence factors were identified: cytotoxin-associated protein A (CagA) and vacuolating cytotoxin A (VacA). Following H. pylori infection, CagA infuses the gastric mucosa through type IV secretion systems and is phosphorylated, activating a kinase cascade, which results in cellular changes and inflammatory cytokine production [11-13]. VacA, secreted by the type $V$ secretion system, induces cytoplasmic vacuole formation $[11,14,15]$. During translocation to the host, VacA interacts with host-cell mitochondria, which activates the caspase cascade and apoptosis [16-19]. Upon $H$. pylori infection recognition, major inflammatory cytokines such as interleukin (IL)-1 $\beta$, IL-6, IL-8, and tumor necrosis factor alpha $(\mathrm{TNF}-\alpha)$ are generated and induce inflammation. The abundance of the pro-inflammatory cytokines is associated with the level of chronic gastritis; this association diminishes in the presence of gastric atrophy or intestinal metaplasia [20]. IL-8 is a neutrophil-activating chemokine in gastric epithelial cells, making it particularly important in H. pylori infection [21].

Gastric mucin is an essential component in the mucosal barriers against a variety of insults. The mucosal defense system protects from mucosal injuries to maintain elasticity and permselectivity of the mucus gel and interferes with $H$. pylori colonization [22,23]. The maintenance of the mucous layer's mucosal defense system and mucinous contents are affected by diverse gastroprotective agents including sulglycotide [24]. Sulglycotide is derived from pig duodenal mucin and is produced by extensive proteolysis. Esterification of its carbohydrate chains with sulfate groups generates a potent gastroprotective agent for the treatment of various gastric diseases [10]. Previous studies have shown that sulglycotide modulates the extent of gastric mucus inflammation via the lipopolysaccharide-mediated nuclear factor kappa B (NF-kB) signaling pathway [25] and downregulated nitric oxide synthase 2 and caspase 3 [26].

Recently, the failure rate of treatment for H. pylori infection is high due to antibiotic resistance, although the success of the treatment depends on several factors such as smoking or patient compliance $[27,28]$. In particular, clarithromycin resistance in Asia has greatly increased from $15.28 \%$ in 2009 to $32.46 \%$ in 2014 [29]. Furthermore, metronidazole resistance has already been detected at rates of more than 15\% worldwide (America 44\%, Africa 92\%, Asia 37\%, and Europe 17\%), and the levofloxacin resistance rate is more than 15\% in Europe (24\%) [30]. Therefore, new therapeutic combinations are needed to minimize the resistance of $\mathrm{H}$. pylori. In this regard, we investigated the inhibitory effects of sulglycotide on adhesion and inflammation following $H$. pylori infection in human gastric adenocarcinoma cells (AGS cells).

\section{Results}

A broth dilution test was performed to investigate the effect of sulglycotide on the growth of H. pylori. Mueller-Hinton broth containing 25, 50, 75, 100, and $200 \mathrm{mg} / \mathrm{L}$ concentrations of sulglycotide were prepared, and H. pylori was grown for 72 hours at each of these concentrations. Sulglycotide did not inhibit the growth of $H$. pylori at any of the tested concentrations, but growth varied depending on the concentration (Figure 1).

A urease assay was performed to determine the quantity of H. pylori that adhered to the surface of the AGS cells. Sulglycotide did not affect the urease activity of $H$. pylori without AGS cells. H. pylori-only infected the control, sulglycotide-pretreated H. pylori, and clarithromycin-pretreated H. pylori was added to the AGS cells. After six, 12, or 24 hours, H. pylori noninfected AGS cells lacked a urease reaction. Compared to the H. pylori-only infected control, bacterial adhesion to AGS cells was inhibited in a sulglycotide dose-dependent manner. Particularly, bacterial adhesion was reduced to 39,44 , or 69 percent in bacteria pretreated with $200 \mathrm{mg} / \mathrm{L}$ sulglycotide for six, 12, or 24 hours of infection, respectively (Figure 2). Sulglycotide treatment with $H$. pylori leads to highly significant adhesion inhibition $(p<0.001)$. Although the bacterial adhesion level was similar at six and 12 hours, the inhibition of adhesion after six hours of infection was more similar to the clarithromycin pretreated 
H. pylori infected controls (Figure 2A,B). It was also confirmed that the colony-forming units (CFUs) of bacteria attached to the cells significantly decreased by sulglycotide during six hours of infection (Figure 3).

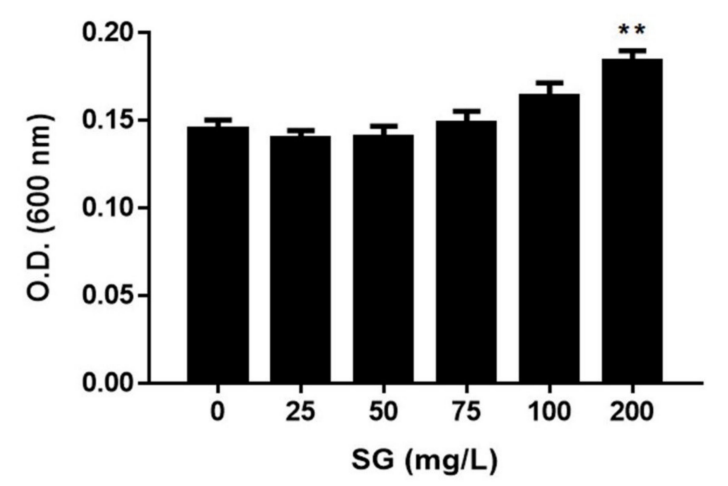

Figure 1. Effect of sulglycotide on the growth of H. pylori. H. pylori was grown in Mueller-Hinton broth containing indicated concentrations of sulglycotide $(25,50,75,100$, and $200 \mathrm{mg} / \mathrm{L})$. After 72 hours of incubation, the final optical density of the bacterial suspension was measured at a $600 \mathrm{~nm}$ wavelength by spectrophotometry. Results from triplicate experiments were analyzed by the Student's $t$-test (** $p<0.01$ and $\left.{ }^{* * *} p<0.001\right)$. O.D.; optical density, SG; sulglycotide.

(A)

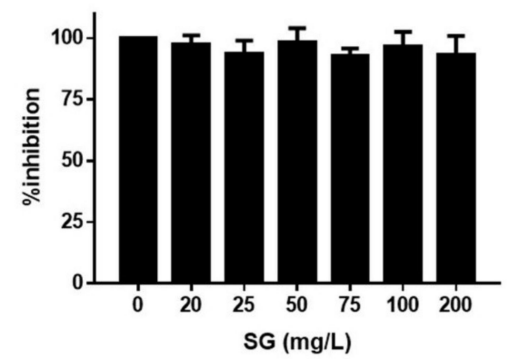

(C)

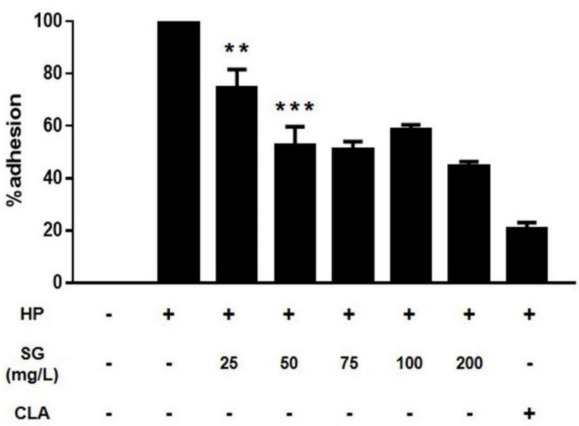

(B) 6 hour infection

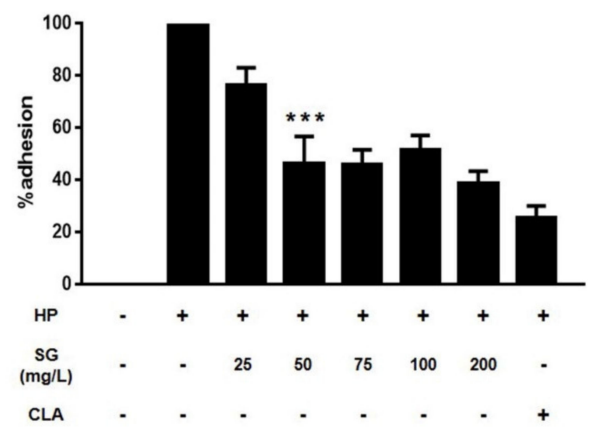

(D)

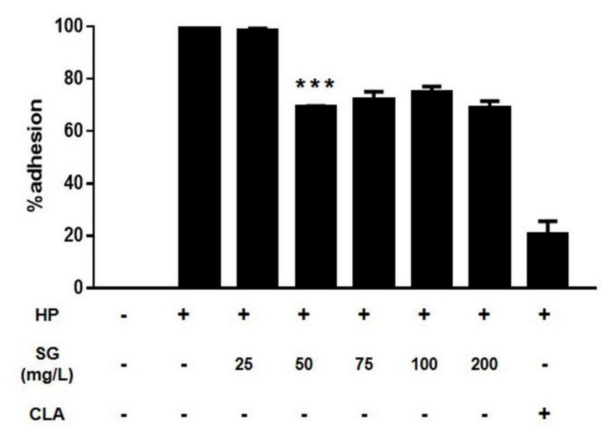

Figure 2. Inhibitory effect of sulglycotide on $H$. pylori adhesion to AGS cells. (A) AGS cells were infected with H. pylori (200 MOI) that had been pretreated with indicated concentrations of sulglycotide $(25,50$, 75, 100, and $200 \mathrm{mg} / \mathrm{L}$ ) for one hour. After (B) 6, (C) 12, or (D) 24 hours of infection, the urease test was performed to analyze the quantity of bacteria that adhered to the surface of the AGS cells. Results from triplicate experiments were analyzed by the Student's $t$-test ${ }^{*} p<0.05$, ${ }^{* *} p<0.01$, and ${ }^{* * *} p<0.001$ ). AGS; human gastric adenocarcinoma, HP; H. pylori, MOI; multiplicity of infection, SG; sulglycotide, CLA; $8 \mu \mathrm{g} / \mathrm{mL}$ of clarithromycin. 


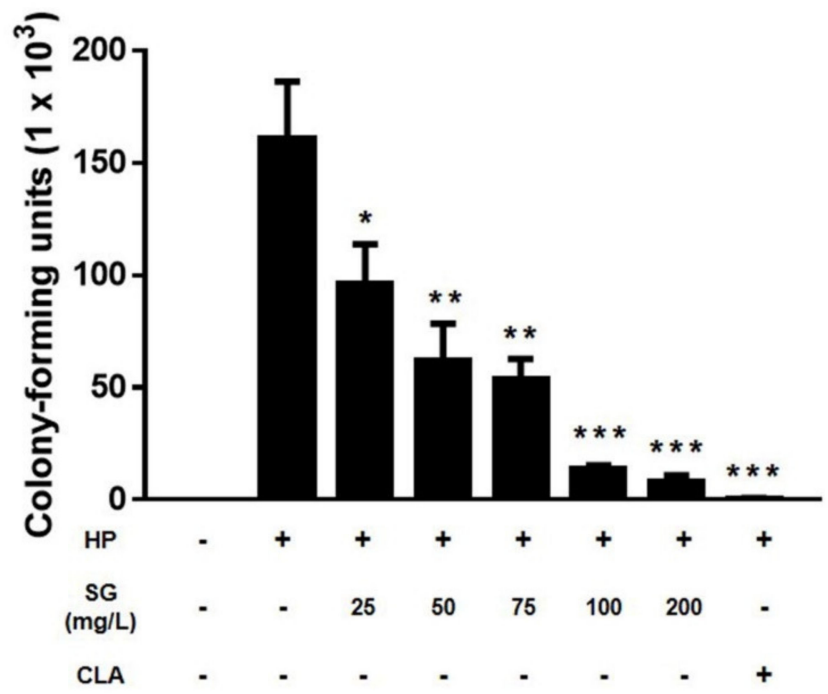

Figure 3. Reduction of the number of $H$. pylori attached to AGS cells by sulglycotide. AGS cells were infected with $H$. pylori (200 MOI) that had been pretreated with indicated concentrations of sulglycotide $(25,50,75,100$, and $200 \mathrm{mg} / \mathrm{L})$ for one hour. After six hours of infection, the cells were lysed with $0.1 \%$ saponin and the lysates were spread on the agar plates. After three days, the number of colonies was counted. AGS; human gastric adenocarcinoma, HP; H. pylori, MOI; multiplicity of infection, SG; sulglycotide, CLA; $8 \mu \mathrm{g} / \mathrm{mL}$ of clarithromycin. $\left({ }^{*} p<0.05,{ }^{* *} p<0.01\right.$, and $\left.{ }^{* *} p<0.001\right)$.

To investigate the protein level of bacterial proteins in AGS cells, AGS cells were infected with H. pylori that had been pretreated with sulglycotide for one hour. After six hours, the cell lysates were harvested and subjected to western blotting. The CagA and VacA proteins were translocated to H. pylori-infected cells, and both CagA and VacA secretion decreased following sulglycotide treatment (Figure 4).

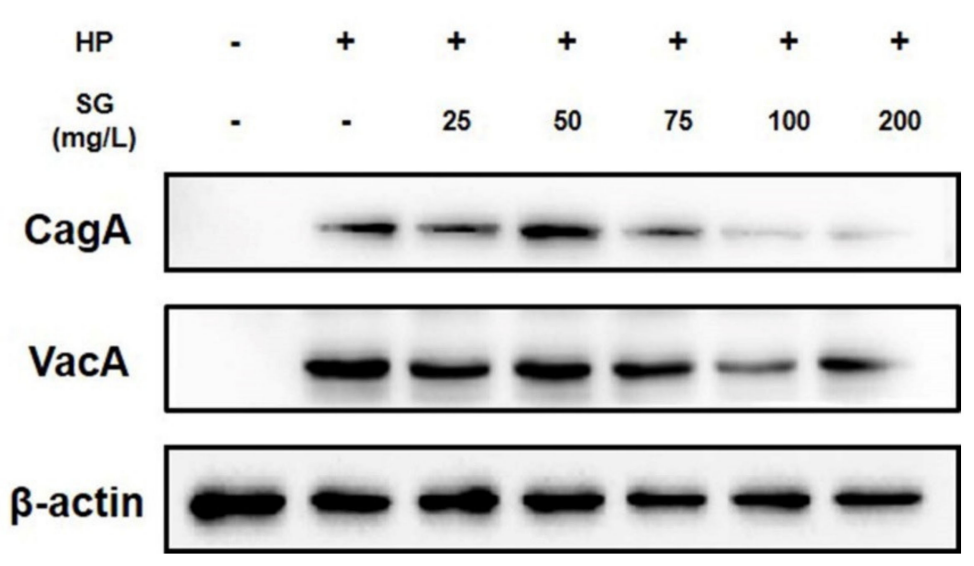

Figure 4. Inhibitory effect of sulglycotide on translocation of virulence factors to AGS cells by H. pylori. AGS cells were infected with H. pylori (200 MOI) that had been pretreated with indicated concentrations of sulglycotide $(25,50,75,100$, and $200 \mathrm{mg} / \mathrm{L})$ for one hour. After six hours, the cell lysates were subjected to western blotting to detect CagA and VacA proteins. $\beta$-actin was used as an internal control. AGS; human gastric adenocarcinoma, CagA; cytotoxin-associated protein A, HP; H. pylori, MOI; multiplicity of infection, SG; sulglycotide, VacA; vacuolating cytotoxin A.

Chemokine IL-8 secretion is induced by H. pylori and plays a central role in gastritis pathogenesis. AGS cells were infected with H. pylori pretreated with sulglycotide and assessed 
for IL-8 protein abundance to evaluate the anti-inflammatory effects of sulglycotide on $H$. pylori infection. IL-8 expression in AGS cells infected with $\mathrm{H}$. pylori was inhibited by sulglycotide (Figure 5).

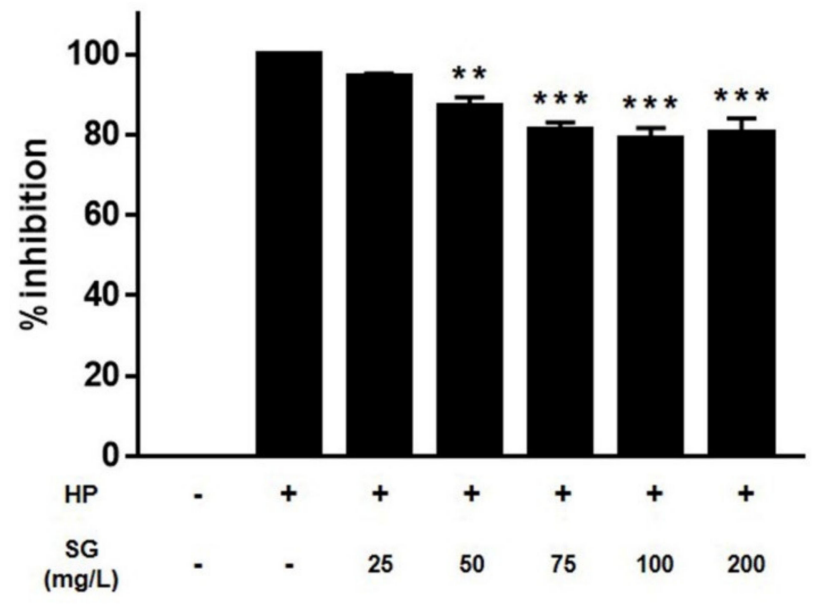

Figure 5. Sulglycotide decreases IL-8 secretion in the supernatant. AGS cells were infected with H. pylori (200 MOI) that had been pretreated with indicated concentrations of sulglycotide $(25,50,75$, 100 , and $200 \mathrm{mg} / \mathrm{L}$ ) for one hour. Culture medium was collected after six hours. ELISA was performed to determine the amount of IL- 8 secretion. Results from triplicate experiments were analyzed by the Student's $t$-test ${ }^{* *} p<0.01$ and ${ }^{* * *} p<0.001$ ). AGS; human gastric adenocarcinoma, ELISA; enzyme-linked immunosorbent assay, HP; H. pylori, MOI; multiplicity of infection, SG; sulglycotide.

\section{Discussion}

An inflammatory tumor microenvironment is associated with cancer progression [31,32]. H. pylori infection increases chronic inflammation in gastric microenvironments and upregulates the production of pro-inflammatory cytokines such as TNF- $\alpha$, IL-1 $\beta$, IL-6, and IL- 8 through an influx of immune cells (e.g., macrophages) in the gastric mucosa [33]. These cytokines bind to specific receptors expressed on gastric epithelial cells; overexpression induces uncontrollable gastric epithelial cell proliferation, resulting in tumorigenesis and the development of gastric cancer [34,35]. Therefore, it is vital to minimize gastric mucosa damage following $H$. pylori infection to maintain mucosal homeostasis. Acquired antibiotic resistance by $H$. pylori following infection is a major concern in South Korea and worldwide. Therefore, it is necessary to identify new agents that minimize resistance of the treatment for H. pylori infection.

This study shows the inhibitory effects of sulglycotide on the adhesion and inflammation of H. pylori. Sulglycotide did not have a direct effect on $H$. pylori growth, therefore, we assumed that it would disrupt colonization of $H$. pylori in the gastric epithelium. Sulglycotide itself was not affected by urease activity of $H$. pylori in contrast to the report by Slomiany et al. [36]. Using a urease assay, we found that $H$. pylori adhesion to AGS cells was inhibited by sulglycotide in a dose-dependent manner, which was consistent with the results of counting the number of bacteria attached to the cells. Additionally, adhesion inhibition observed in cells six hours post-infection was more similar to the clarithromycin pretreated $H$. pylori infected control than the cells 12 hours after infection. Therefore, the most effective, six hours of infection treated with sulglycotide, was applied to further experiments. Collectively, these data indicate that sulglycotide has an effect on inhibiting the initial stage of the colonization process.

Inhibition of bacterial adhesion decreases the entry of bacterial proteins into host cells. H. pylori strains harbor multiple virulence factors such as CagA and VacA that increase inflammation of the gastric mucosa and injuries to gastric epithelial cells [37]. In H. pylori-infected AGS cells treated with sulglycotide, the levels of CagA and VacA proteins decreased, suggesting that sulglycotide diminishes the translocation of CagA and VacA. When H. pylori infects the stomach, major inflammatory cytokines 
are upregulated in the gastric epithelial cells, causing gastric and duodenal ulcers to develop. A previous study has reported that IL-8 is one of the early pro-inflammatory cytokines produced by gastric epithelial cells in response to H. pylori infection [21]. Through enzyme-linked immunosorbent assay (ELISA), we showed that sulglycotide decreases the level of IL-8, supporting the fact that sulglycotide impacts anti-inflammatory reactions to $H$. pylori infection.

In conclusion, sulglycotide inhibited bacterial adhesion and inflammation after H. pylori infection in AGS cells in vitro. This might mean that sulglycotide has an effect on inhibiting the initial stage of the colonization process. These results support that sulglycotide is a potential therapeutic option for the treatment of $H$. pylori infection and future in vivo studies and clinical trials are needed.

\section{Methods}

\subsection{Materials}

H. pylori reference strain was purchased from American Type Culture Collection (ATCC 49503, Manassas, VA, USA). Mueller-Hinton broth and Brucella agar were purchased from Becton-Dickinson (Braintree, MA, USA). Bovine serum was purchased from Gibco (Long Island, NY, USA). AGS gastric adenocarcinoma cells (ATCC CRL-1739) were purchased from ATCC. Clarithromycin was purchased from BRL Life Technologies (Grand Island, NY, USA) for adhesion assays. Protease inhibitor cocktails were obtained from Sigma-Aldrich (Saint Louis, MO, USA). Antibodies to detect CagA, VacA, and $\beta$-actin were purchased from Santa Cruz Biotechnology (Dallas, TX, USA). A human IL-8 ELISA kit was purchased from Invitrogen (Carlsbad, CA, USA). Sulglycotide (Gliptide ${ }^{\circledR}$ ) was kindly donated by the Samil Pharmaceutical Company.

\subsection{Bacterial and Mammalian Cell Culture}

H. pylori was cultured on Brucella agar supplemented with 10\% bovine serum and incubated at $37^{\circ} \mathrm{C}\left(100 \%\right.$ humidity) for 72 hours in microaerophilic conditions with $5 \% \mathrm{CO}_{2}$. AGS cells were cultured in Dulbecco's Modified Eagle's Medium (DMEM) supplemented with 10\% fetal bovine serum (FBS), $100 \mu \mathrm{g} / \mathrm{mL}$ streptomycin, and $100 \mathrm{U} / \mathrm{mL}$ penicillin. AGS cells were incubated at $37^{\circ} \mathrm{C}$ in a humidified atmosphere with $5 \% \mathrm{CO}_{2}$.

\subsection{Broth Dilution Method}

Bacterial colonies were collected and suspended in Mueller-Hinton broth supplemented with $10 \%$ bovine serum for cultivation. The number of $H$. pylori cells was set to McFarland $0.33\left(1 \times 10^{8} \mathrm{CFU} / \mathrm{mL}\right)$ and incubated at $37{ }^{\circ} \mathrm{C}$ for three days in a humidified atmosphere with $5 \% \mathrm{CO}_{2}$. Bacterial growth was measured at a wavelength of $600 \mathrm{~nm}$. The control group was inoculated with bacteria in medium without sulglycotide and then cultured in the same manner as the experimental group. All experiments were repeated three times.

\subsection{Urease Activity Test}

H. pylori was treated with the indicated concentrations of sulglycotide $(25,50,75,100$, and $200 \mathrm{mg} / \mathrm{L}$ ). After 72 hours, $100 \mu \mathrm{L}$ of the medium was collected, centrifuged at $3000 \mathrm{rpm}$ for 10 minutes, and then separated into the supernatant and cells. The supernatant was quantified by measuring the optical density at $600 \mathrm{~nm}$ using a NanoQuant Infinite M200. After adding $5 \mu \mathrm{L}$ of $20 \%$ urea to the specimens respectively, the specimens were incubated at $37^{\circ} \mathrm{C}$ for 10 minutes. Urease activity was determined by using an Asan Set Ammonia Kit (Asan Pharmaceutical, Seoul, Korea) to measure the ammonia levels, according to manufacturer's instructions.

\subsection{Adhesion Test}

AGS cells were seeded in 6-well culture plates at a density of $2 \times 10^{5} / 2 \mathrm{~mL}$ cells in DMEM to form a confluent monolayer, and infected with $H$. pylori at a multiplicity of infection (MOI) of 
200 that had been pretreated with various doses $(25,50,75,100$, and $200 \mathrm{mg} / \mathrm{L})$ of sulglycotide for one hour. Two control groups were included: noninfected AGS cells and AGS cells infected with H. pylori pretreated with clarithromycin at a concentration of $8 \mu \mathrm{g} / \mathrm{mL}$. After an indicated period of infection, the monolayer was washed twice with phosphate-buffered saline (PBS) to remove the unattached bacteria. To determine the number of bacteria attached to cells, cells were lysed by $0.1 \%$ saponin followed by incubation for five minutes at room temperature and was spread on Brucella agar supplemented with $10 \%$ bovine serum. The CFU was counted after three days of incubation. The urease test was performed by adding $2 \mathrm{~mL}$ of urease test solution $(7 \mathrm{mM}$ phosphate buffer, $\mathrm{pH} 6.8$, $110 \mathrm{mM}$ urea, $10 \mathrm{mg} / \mathrm{L}$ phenol red) to each sample. After $60 \mathrm{~min}$, the absorbance values at $540 \mathrm{~nm}$ were recorded using a Nano-Quant spectrophotometer [38].

\subsection{Western Blotting}

AGS cells were washed twice with PBS and then lysed with a radioimmunoprecipitation assay (RIPA) buffer containing a protease inhibitor cocktail. The cell lysates were incubated on ice for $10 \mathrm{~min}$ and then centrifuged, and the supernatant was collected. Thirty $\mu \mathrm{g}$ of CagA and VacA proteins and $10 \mu \mathrm{g}$ of UreA, UreB, and $\beta$-actin proteins were loaded on a sodium dodecyl sulfate (SDS)-polyacrylamide gel. The proteins were separated using SDS-polyacrylamide gel electrophoresis and transferred to a nitrocellulose membrane. The membrane was incubated at optimal concentrations with the primary antibody (CagA, VacA, UreA, UreB, and $\beta$-actin) at $4{ }^{\circ} \mathrm{C}$ overnight, and then incubated with the appropriate secondary antibody (anti-mouse or anti-rabbit) for two hours at room temperature. The immune-labeled proteins were visualized using enhanced chemiluminescence (ECL). $\beta$-actin was used as an internal control for mammalian cell proteins.

\subsection{Enzyme-Linked Immunosorbent Assay (ELISA)}

AGS cells were infected with $H$. pylori that had been pretreated with sulglycotide $(25,50,75,100$, and $200 \mathrm{mg} / \mathrm{L}$ ). After one hour of infection, cells were harvested to measure IL-8 cytokine abundance. AGS cells were washed twice with PBS, lysed with RIPA buffer, and centrifuged; the supernatant of each sample was collected. IL-8 concentrations were determined using a human IL-8 ELISA kit. This assay used a solid-phase sandwich enzyme immunoassay that included monoclonal antibodies raised against the respective cytokines. All procedures were performed using the manufacturer's protocol. Cytokine concentrations of unknown samples were determined by interpolation using a standard curve based on recombinant IL- 8 supplied by the manufacturer.

\subsection{Statistical Analysis}

Each experiment was repeated in triplicate and data in the bar graphs were presented as mean \pm standard error of mean (SEM). All statistical analyses were performed using GraphPad Prism 6 software (GraphPad Software, San Diego, CA, USA). All data were analyzed with one-way analysis of variance (ANOVA) and $p<0.05$ was considered to be statistically significant $\left({ }^{*} p<0.05,{ }^{* *} p<0.01\right.$, and $\left.{ }^{* * *} p<0.001\right)$.

Author Contributions: P.K. and J.-B.K. conceived the study and provided overall direction. J.Y.Y., and S.-H.J. wrote the manuscript. J.Y.Y., S.-H.J., P.K., S.W.L. and J.-B.K. designed the experiments. J.Y.Y. performed the experiments. J.Y.Y., M.K.B., and Y.S.M. analyzed the data. S.-H.J. and J.-B.K. reviewed the manuscript. All authors have read and agreed to the published version of the manuscript.

Funding: This study was funded by the Samil Pharmaceutical Company.

Conflicts of Interest: The funders had no role in the study design, data collection and analysis, decision to publish, or preparation of the manuscript. 


\section{References}

1. Schistosomes, Liver Flukes and Helicobacter pylori. IARC Monogr. Eval. Carcinog. Risks Hum. IARC Working Group on the Evaluation of Carcinogenic Risks to Humans. Available online: https: //www.ncbi.nlm.nih.gov/books/NBK487782/pdf/Bookshelf_NBK487782.pdf (accessed on 28 March 2011).

2. El-Omar, E.M.; Oien, K.; El-Nujumi, A.; Gillen, D.; Wirz, A.; Dahill, S.; Williams, C.; Ardill, J.E.; McColl, K.E. Helicobacter pylori infection and chronic gastric acid hyposecretion. Gastroenterology 1997, 113, 15-24. [CrossRef]

3. Hamlet, A.; Thoreson, A.C.; Nilsson, O.; Svennerholm, A.M.; Olbe, L. Duodenal Helicobacter pylori infection differs in cagA genotype between asymptomatic subjects and patients with duodenal ulcers. Gastroenterology 1999, 116, 259-268. [CrossRef]

4. Amieva, M.; Peek, R.M., Jr. Pathobiology of Helicobacter pylori-Induced Gastric Cancer. Gastroenterology 2016, 150, 64-78. [CrossRef] [PubMed]

5. Suerbaum, S.; Michetti, P. Helicobacter pylori infection. N. Engl. J. Med. 2002, 347, 1175-1186. [CrossRef] [PubMed]

6. Uemura, N.; Okamoto, S.; Yamamoto, S.; Matsumura, N.; Yamaguchi, S.; Yamakido, M.; Taniyama, K.; Sasaki, N.; Schlemper, R.J. Helicobacter pylori infection and the development of gastric cancer. N. Engl. J. Med. 2001, 345, 784-789. [CrossRef] [PubMed]

7. Yim, J.Y.; Kim, N.; Choi, S.H.; Kim, Y.S.; Cho, K.R.; Kim, S.S.; Seo, G.S.; Kim, H.U.; Baik, G.H.; Sin, C.S.; et al. Seroprevalence of Helicobacter pylori in South Korea. Helicobacter 2007, 12, 333-340. [CrossRef]

8. Slomiany, B.L.; Piotrowski, J.; Slomiany, A. Induction of caspase-3 and nitric oxide synthase-2 during gastric mucosal inflammatory reaction to Helicobacter pylori lipopolysaccharide. Biochem. Mol. Biol. Int. 1998, 46, 1063-1070. [CrossRef]

9. Piotrowski, J. Lipopolysaccharide a virulence factor of Helicobacter pylori: Effect of antiulcer agents. J. Physiol. Pharmacol. 1998, 49, 3-24.

10. Slomiany, B.L.; Piotrowski, J.; Slomiany, A. Anti-Helicobacter pylori activities of ebrotidine. A review of biochemical and animal experimental studies and data. Arzneimittelforschung 1997, 47, 475-482.

11. Stein, M.; Bagnoli, F.; Halenbeck, R.; Rappuoli, R.; Fantl, W.J.; Covacci, A. c-Src/Lyn kinases activate Helicobacter pylori CagA through tyrosine phosphorylation of the EPIYA motifs. Mol. Microbiol. 2002, 43, 971-980. [CrossRef]

12. Higashi, H.; Tsutsumi, R.; Muto, S.; Sugiyama, T.; Azuma, T.; Asaka, M.; Hatakeyama, M. SHP-2 tyrosine phosphatase as an intracellular target of Helicobacter pylori CagA protein. Science 2002, 295, 683-686. [CrossRef] [PubMed]

13. Backert, S.; Ziska, E.; Brinkmann, V.; Zimny-Arndt, U.; Fauconnier, A.; Jungblut, P.R.; Naumann, M.; Meyer, T.F. Translocation of the Helicobacter pylori CagA protein in gastric epithelial cells by a type IV secretion apparatus. Cell. Microbiol. 2000, 2, 155-164. [CrossRef] [PubMed]

14. Saadat, I.; Higashi, H.; Obuse, C.; Umeda, M.; Murata-Kamiya, N.; Saito, Y.; Lu, H.; Ohnishi, N.; Azuma, T.; Suzuki, A.; et al. Helicobacter pylori CagA targets PAR1/MARK kinase to disrupt epithelial cell polarity. Nature 2007, 447, 330-333. [CrossRef]

15. Hatakeyama, M. Oncogenic mechanisms of the Helicobacter pylori CagA protein. Nat. Rev. Cancer 2004, 4, 688-694. [CrossRef]

16. Cover, T.L.; Krishna, U.S.; Israel, D.A.; Peek, R.M., Jr. Induction of gastric epithelial cell apoptosis by Helicobacter pylori vacuolating cytotoxin. Cancer Res. 2003, 63, 951-957. [PubMed]

17. Kuck, D.; Kolmerer, B.; Iking-Konert, C.; Krammer, P.H.; Stremmel, W.; Rudi, J. Vacuolating cytotoxin of Helicobacter pylori induces apoptosis in the human gastric epithelial cell line AGS. Infect. Immun. 2001, 69, 5080-5087. [CrossRef] [PubMed]

18. Galmiche, A.; Rassow, J.; Doye, A.; Cagnol, S.; Chambard, J.C.; Contamin, S.; de Thillot, V.; Just, I.; Ricci, V.; Solcia, E.; et al. The N-terminal $34 \mathrm{kDa}$ fragment of Helicobacter pylori vacuolating cytotoxin targets mitochondria and induces cytochrome $c$ release. EMBO J. 2000, 19, 6361-6370. [CrossRef]

19. McClain, M.S.; Schraw, W.; Ricci, V.; Boquet, P.; Cover, T.L. Acid activation of Helicobacter pylori vacuolating cytotoxin (VacA) results in toxin internalization by eukaryotic cells. Mol. Microbiol. 2000, 37, 433-442. [CrossRef] 
20. Isomoto, H.; Matsushima, K.; Inoue, N.; Hayashi, T.; Nakayama, T.; Kunizaki, M.; Hidaka, S.; Nakayama, M.; Hisatsune, J.; Nakashima, M.; et al. Interweaving microRNAs and proinflammatory cytokines in gastric mucosa with reference to H. pylori infection. J. Clin. Immunol. 2012, 32, 290-299. [CrossRef]

21. Fox, J.G.; Wang, T.C. Inflammation, atrophy, and gastric cancer. J. Clin. Investig. 2007, 117, 60-69. [CrossRef]

22. Slomiany, B.L.; Piotrowski, J.; Czajkowski, A.; Murty, V.L.; Slomiany, A. Characterization of gastric mucosal mucin receptor. Biochem. Mol. Biol. Int. 1993, 31, 745-753.

23. Lord, D.A.; McLaren, J.W.; Wheeler, R.C. Determination of trace metals in fresh water mussels by atomic absorption spectrometry with direct solid sample injection. Anal. Chem. 1977, 49, 257-261. [CrossRef] [PubMed]

24. Piotrowski, J.; Majka, J.; Murty, V.L.; Czajkowski, A.; Slomiany, A.; Slomiany, B.L. Inhibition of gastric mucosal mucin receptor by Helicobacter pylori lipopolysaccharide: Effect of sulglycotide. Gen. Pharmacol. 1994, 25, 969-976. [CrossRef]

25. Slomiany, B.L.; Piotrowski, J.; Slomiany, A. Suppression of gastric mucosal inflammatory responses to Helicobacter pylori lipopolysaccharide by sulglycotide. Gen. Pharmacol. 1999, 32, 251-257. [CrossRef]

26. Slomiany, B.L.; Piotrowski, J.; Slomiany, A. Gastric mucosal inflammatory responses to Helicobacter pylori lipopolysaccharide: Down-regulation of nitric oxide synthase-2 and caspase-3 by sulglycotide. Biochem. Biophys. Res. Commun. 1999, 261, 15-20. [CrossRef] [PubMed]

27. Camargo, M.C.; Piazuelo, M.B.; Mera, R.M.; Fontham, E.T.; Delgado, A.G.; Yepez, M.C.; Ceron, C.; Bravo, L.E.; Bravo, J.C.; Correa, P. Effect of smoking on failure of H. pylori therapy and gastric histology in a high gastric cancer risk area of Colombia. Acta Gastroenterol. Latinoam. 2007, 37, 238-245.

28. Suzuki, T.; Matsuo, K.; Ito, H.; Sawaki, A.; Hirose, K.; Wakai, K.; Sato, S.; Nakamura, T.; Yamao, K.; Ueda, R.; et al. Smoking increases the treatment failure for Helicobacter pylori eradication. Am. J. Med. 2006, 119, 217-224. [CrossRef]

29. Ghotaslou, R.; Leylabadlo, H.E.; Asl, Y.M. Prevalence of antibiotic resistance in Helicobacter pylori: A recent literature review. World J. Methodol. 2015, 5, 164-174. [CrossRef]

30. De Francesco, V.; Giorgio, F.; Hassan, C.; Manes, G.; Vannella, L.; Panella, C.; Ierardi, E.; Zullo, A. Worldwide H. pylori antibiotic resistance: A systematic review. J. Gastrointest. Liver Dis. 2010, 19, 409-414.

31. Bruchard, M.; Rebe, C.; Derangere, V.; Togbe, D.; Ryffel, B.; Boidot, R.; Humblin, E.; Hamman, A.; Chalmin, F.; Berger, H.; et al. The receptor NLRP3 is a transcriptional regulator of TH2 differentiation. Nat. Immunol. 2015, 16, 859-870. [CrossRef]

32. Lu, H.; Ouyang, W.; Huang, C. Inflammation, a key event in cancer development. Mol. Cancer Res. 2006, 4, 221-233. [CrossRef] [PubMed]

33. Lamb, A.; Chen, L.F. Role of the Helicobacter pylori-induced inflammatory response in the development of gastric cancer. J. Cell. Biochem. 2013, 114, 491-497. [CrossRef] [PubMed]

34. Tu, S.; Bhagat, G.; Cui, G.; Takaishi, S.; Kurt-Jones, E.A.; Rickman, B.; Betz, K.S.; Penz-Oesterreicher, M.; Bjorkdahl, O.; Fox, J.G.; et al. Overexpression of interleukin-1beta induces gastric inflammation and cancer and mobilizes myeloid-derived suppressor cells in mice. Cancer Cell 2008, 14, 408-419. [CrossRef] [PubMed]

35. El-Omar, E.M.; Carrington, M.; Chow, W.H.; McColl, K.E.; Bream, J.H.; Young, H.A.; Herrera, J.; Lissowska, J.; Yuan, C.C.; Rothman, N.; et al. Interleukin-1 polymorphisms associated with increased risk of gastric cancer. Nature 2000, 404, 398-402. [CrossRef] [PubMed]

36. Piotrowski, J.; Slomiany, A.; Slomiany, B.L. Suppression of Helicobacter pylori protease activity towards growth factors by sulglycotide. J. Physiol. Pharmacol. 1997, 48, 345-351. [PubMed]

37. Cover, T.L.; Blaser, M.J. Helicobacter pylori in health and disease. Gastroenterology 2009, 136, $1863-1873$. [CrossRef]

38. Tharmalingam, N.; Kim, S.H.; Park, M.; Woo, H.J.; Kim, H.W.; Yang, J.Y.; Rhee, K.J.; Kim, J.B. Inhibitory effect of piperine on Helicobacter pylori growth and adhesion to gastric adenocarcinoma cells. Infect. Agents Cancer 2014, 9, 43. [CrossRef]

(C) 2020 by the authors. Licensee MDPI, Basel, Switzerland. This article is an open access article distributed under the terms and conditions of the Creative Commons Attribution (CC BY) license (http://creativecommons.org/licenses/by/4.0/). 